\title{
Comparative Functional HRM Practices in Nepalese Banking and Insurance Companies
}

\author{
Dr. Prakash Shrestha \\ Lecturer, Nepal Commerce Campus, Tribhuvan University, Nepal \\ Dr. Dilip Parajuli* \\ Associate Professor, Bhaktapur Multiple Campus, Tribhuvan University, Nepal \\ *E-mail of the corresponding author: dilipparajuli2020@gmail.com
}

\begin{abstract}
The main objective of this research is to examine the core aspects of the practices of functional human resource management (HRM) in Nepalese commercial banks and insurance companies. This research is focused on primary sources of data. Data was gathered from 10 commercial banks and 10 insurance companies of Nepal by creating a set of questionnaires and distributing these questionnaires to the officer-level employees of each of the commercial banks and insurance companies. The findings point out that there are significant differences between commercial banks and insurance companies in functional HRM practices in terms of employee selection and placement and in the management of pay \& bonus schemes. Commercial banks are often found to typically have a higher level of HRM practices, while insurance companies have a lower level of HRM practices. There is a possibility of the mobility of human resources from insurance companies to commercial banks. Therefore, both commercial banks and insurance companies in Nepal must ensure that investment in their human resources and HRM practices definitely attract and retain competent people from the job market.
\end{abstract}

Keywords: Human resource management, Employees, Practices, Commercial banks, Insurance companies DOI: $10.7176 / \mathrm{EJBM} / 12-30-01$

Publication date:October $31^{\text {st }} 2020$

\section{Introduction}

Human resources work efficiently to achieve organizational goals, provide quality services, and produce goods to compete in national or international markets in order to earn a profit. They can provide a competitive advantage to companies (Shrestha, 2019). So, it is now commonly accepted that employees create an important source of competitive advantages for the companies (Barney, 1991, Pfeffer, 1994). Therefore, it is imperative for companies to pursue human resource management (HRM) practices that ensure the effective use of their human resources. Some previous HRM-related studies (e.g., Dyer and Reeves, 1995; Becker and Gerhart, 1996; Guest, 1997; Becker and Huselid, 1998) reported that higher results and outcomes can be obtained by the companies that match up to their HRM practices with the business strategy.

HRM activities are likely to create working conditions and environments in which workers are strongly devoted to the organization (have a positive attitude) and do their best to achieve the goals of the organization (Cherif, 2020). The practices of HRM have grown very popular over the past decades, and it has become a common characteristic for nearly all larger companies and many smaller ones in today's context. It is assumed that HRM is a source for competitive advantage and will influence the organizational results and performance in a positive direction. Nowadays, organizations, mainly of the service industry, need to ensure maximum utilization of their resources to their own advantage; a necessity for organizational survival in today's competitive and rapidly changing business world. Barney (1991) says that organizations can create and sustain a competitive position through the management of non-substitutable, rare, valuable, and inimitable internal resources.

HRM became a very crucial problem in Nepal with increased competition in the financial sector (Shrestha and Parajuli, 2020). In commercial banks and insurance companies employee turnover is normal. Thus, these organizations need to keep an eye open for successful HRM in this problem. Through applying HR policies and practices that focus on hiring, identifying, educating trained employees, and guiding their best efforts to cooperate within the organization's resource package, HRM practices may also create business organizations that are more intelligent, agile, and knowledgeable than their rivals (Quansah, 2013). Therefore, this study aims to explore the key dimensions of functional HRM practices in Nepalese commercial banks and insurance companies. It also aims to compare the functional HRM practices adopted by these commercial banks and insurance companies.

\section{Literature Review}

The secret to organizational success is human resources or employees (Shrestha, 2013, 2016). It is important for organizations to concentrate such human resources (Shrestha, 2020). According to Jackson and Schuler (1995), HRM practices can be almost everything coupled with the management of employment relations within an organization. They argued that HRM practices consist of that system, which attracts, develops, motivates, and 
retains employees to ensure the effective implementation and the survival of the organization and its members. Mainly four main approaches can be found in the literature to develop HRM: "universal" or "best practice" approach (Huselid, 1995); strategic HRM practices approach (Delery \& Doty, 1996); contingency approach (Dyer, 1985; Schuler, 1989); and configuration approach (Wright \& McMahan, 1992 cited in Ling \& Mohd, 2010). Many recent studies (e.g. Guest, 1999; 2003; Harel, 1999; Quansah, 2013; Mizanur, Mohammad, \& Mohammad, 2013; Uma, Aurolipy, \& Madhusmita, 2017; Alima \& Faizuniah, 2018; Ana, Gisela, \& Tatiane, 2019; Elrehail et al., 2019; Mohammed et al., 2019; Cherif, 2020) reported the importance of HRM practices for organizational success. The following Table (1) presents some of the key variables that are taken as the HRM practices:

Table 1: Variables of HRM practices

\begin{tabular}{|c|c|}
\hline Researcher(s)/Date & Variables \\
\hline Delaney, Lewin, \& Ichniowski (1989) & $\begin{array}{l}\text { Selection, performance appraisal, incentive, compensation, } \\
\text { job design, grievance procedures, information sharing, } \\
\text { attitude assessment, labor-management participation. }\end{array}$ \\
\hline Huselid (1995) & $\begin{array}{l}\text { Recruiting intensity, average training hours per year, and the } \\
\text { criteria for the promotion. }\end{array}$ \\
\hline Poole \& Jenkins (1997) & $\begin{array}{l}\text { Employee involvement, training and development, rewards } \\
\text { and work practices }\end{array}$ \\
\hline Laursen \& Foss (2003); Shipton et al. (2005) & $\begin{array}{l}\text { Encompassing performance appraisal, career management, } \\
\text { reward system, training, and recruitment. }\end{array}$ \\
\hline $\begin{array}{l}\text { Qureshi, Tahir Hijazi, Syed Ramey, \& } \\
\text { Mohammad (2007) }\end{array}$ & $\begin{array}{l}\text { Selection, performance appraisal, training, compensation } \\
\text { system and employee participation. }\end{array}$ \\
\hline $\begin{array}{l}\text { Marchington \& Wilkinson (2002); Foot \& Hook } \\
\text { (2005); Jackson, Schuler, \& Werner (2009); } \\
\text { Jaradat \& Azaam, (2013) }\end{array}$ & $\begin{array}{l}\text { Job analysis and design, recruitment process, selection and } \\
\text { placement, training and development, performance } \\
\text { appraisal. }\end{array}$ \\
\hline Elrehail, et al. (2019) & $\begin{array}{l}\text { Human resource planning, job analysis and design, } \\
\text { employee performance appraisal, recruitment, selection and } \\
\text { placement, compensation and reward, training and } \\
\text { development. }\end{array}$ \\
\hline
\end{tabular}

Most of the previous researches reported more or less similar variables of HRM practices. However, we can find most of our organizations have focused on the "universal" or "best practice" approach. Many studies show that these "universal" or "best" HRM practices proposed by different scholars vary (Ferris, Hochwarter, Buckley, Harrell-Cook \& Frink, 1999). For example, Delaney, Lewin, and Ichniowski (1989) utilized some of the "best" HRM practices, which are selection, performance appraisal, incentive, compensation, job design, grievance procedures, information sharing, attitude assessment, labor-management participation (Delaney et al., 1989 as cited in Ferris et al., 1999). Likewise, Huselid (1995) had added three more "best" HRM practices on top of Delaney et al. (1989) list that includes variables such as recruiting intensity, average training hours per year, and the criteria for the promotion. However, in this study employee selection \& placement, training \& development, performance appraisal \& management, and management of pay and bonus schemes are taken into consideration as the key functional HRM practices.

\section{Research Methods \\ 3.1 Participants}

This study is based on primary data. The data were collected through developing a set of questionnaires and distributing these questionnaires to the officer level employees of the 10 commercial banks and 10 insurance companies of Nepal. In total 300 questionnaires (15 in each of the selected 20 organizations) were administered. A total of $189(63 \%)$ copies were returned and were utilized for the purpose of the study. The profile of respondents' of the sampled organizations is presented in the following Table (2): 
Table 2: Respondent's Profile of Selected Organizations (N=189)

\begin{tabular}{|c|l|c|c|}
\hline S.N. & \multicolumn{1}{|c|}{ Selected organizations } & Participants & Positions \\
\hline 1 & Nepal Bank Ltd. & $6.35 \%$ & Officers, Managers \& Department Chiefs \\
\hline 2 & Agriculture Development Bank Ltd. & $6.35 \%$ & Officers, Managers \& Department Chiefs \\
\hline 3 & Nabil Bank Ltd. & $5.29 \%$ & Officers and Managers \\
\hline 4 & Nepal Investment Bank Ltd. & $5.82 \%$ & Officer, Managers and Chiefs \\
\hline 5 & Nepal SBI Bank Ltd. & $12.70 \%$ & Officers, Managers, Chiefs, and Legal \\
\hline 6 & Everest Bank Ltd. & $7.41 \%$ & Officers, Managers, and Chiefs \\
\hline 7 & Bank of Kathmandu Ltd. & $4.23 \%$ & Officers and Managers \\
\hline 8 & Machhapuchhre Bank Ltd. & $4.76 \%$ & Officers, Managers, and Chiefs \\
\hline 9 & Kumari Bank Ltd. & $5.82 \%$ & Officers, Managers, and Chiefs \\
\hline 10 & Siddhartha Bank Ltd. & $4.23 \%$ & Officers and Managers \\
\hline 11 & Rastriya Beema Samsthan & $5.29 \%$ & Officers and Managers \\
\hline 12 & Nepal Insurance Company Ltd. & $3.70 \%$ & Officers and Managers \\
\hline 13 & National Insurance Company Ltd. & $4.23 \%$ & Officers, Managers, and Chiefs \\
\hline 14 & National Life Insurance Company Ltd. & $3.17 \%$ & Officers and Managers \\
\hline 15 & Premier Insurance Company (Nepal) & $2.65 \%$ & Officers and Managers \\
\hline 16 & Everest Insurance Company Ltd. & $4.23 \%$ & Officers and Managers \\
\hline 17 & Neco Insurance Ltd. & $3.17 \%$ & Officers and Managers \\
\hline 18 & Sagarmatha Insurance Company Ltd. & $2.65 \%$ & Officers and Managers \\
\hline 19 & Alliance Insurance Company Ltd & $3.17 \%$ & Officers and Managers \\
\hline 20 & NB Insurance Company Ltd. & $4.76 \%$ & Officers and Managers \\
\hline
\end{tabular}

\subsection{Measurement}

A check-list scale of functional HRM practices developed by Wang and Zang (2005) was used in this study. Each practice item is scaled by $1-5$ points to measure the degree of application. The functional HRM practices are categorized into four areas such as employee selection \& placement, training \& development, performance appraisal \& management, and management of pay \& bonus schemes.

\subsection{Analysis tools}

Simple descriptive statistics such as mean (average), standard deviation (S.D.), and percentage are used to analyze the data. Cronbach's alpha is used to analyze the reliability of the data.

\subsection{Study variables of functional HRM practices}

Table (3) presents the four-category list of study variables of functional HRM practices that are used in this study.

Table 3: Four-category of functional HRM practices

\begin{tabular}{ll}
\hline Category & Indicators \\
\hline \multirow{3}{*}{ Employee selection and placement } & Actions for adaptation of formal procedures \\
& Use of tests in personnel selection and placement \\
& Development of job descriptions for key positions \\
& Specific job requirements for applicants \\
\hline \multirow{2}{*}{ Training and development } & Specific orientation training programs \\
& Periodic training needs analysis \\
& Regular evaluations of training programs \\
& Evaluations on training results and outcomes \\
\hline Performance appraisal and management & Regular performance appraisal activities \\
& Formal procedures and evaluation forms \\
& Tailor-made criteria for performance appraisal \\
& Specific rules for rewards by performance \\
\hline & Specific pay link with performance \\
Management of pay and bonus schemes & Bonus link with monthly performance \\
& Pay link with company profits \\
& Bonus link with different position \\
\hline
\end{tabular}

\section{Results and Findings}

This section presents the empirical results and findings. The first section presents the results of descriptive statistics and the next section presents the results of comparative functional HRM practices in commercial banks and 
insurance companies of Nepal.

\subsection{Descriptive Statistics}

The descriptive statistics for the study variables are tabulated as shown in Table (4).

Table 4: Mean, S.D. and Reliability Coefficients of Functional HRM Dimensions ( $N=189)$

\begin{tabular}{|c|c|c|c|c|}
\hline HRM practices & Measures & Mean & S.D. & $\begin{array}{c}\text { Reliability } \\
\text { Coefficients }\end{array}$ \\
\hline selection and & $\begin{array}{l}\text { Formal procedures, use of tests, job } \\
\text { descriptions and requirements }\end{array}$ & 3.6 & 0.97 & 0.87 \\
\hline Training and development & $\begin{array}{l}\text { Orientation, needs analysis, programs } \\
\text { design and evaluations }\end{array}$ & 3.57 & 0.94 & 0.91 \\
\hline $\begin{array}{l}\text { Performance appr } \\
\text { management }\end{array}$ & $\begin{array}{l}\text { ity, for } \\
\text { and spec }\end{array}$ & 2.9 & 9 & 0.82 \\
\hline $\begin{array}{l}\text { Management of pay and } \\
\text { bonus schemes }\end{array}$ & $\begin{array}{l}\text { onus system, } \\
\text { ed. }\end{array}$ & 3.0 & 4 & 0.87 \\
\hline \multicolumn{5}{|c|}{$\begin{array}{l}\text { Note: Reliability is calculated according to the Alpha value of Cronbach. The Alpha value is greater than } \\
\text { Sekaran's argument (Sekaran, 2006). Therefore, the procedures used to calculate these variables are } \\
\text { reasonably accurate and have useful outcomes. }\end{array}$} \\
\hline \multicolumn{5}{|c|}{$\begin{array}{l}\text { The level of functional HRM practices in terms of employee selection and placement }(\mathrm{M}=3.62, \mathrm{SD}=0.97) \text { is } \\
\text { elatively higher that is followed by training \& development }(\mathrm{M}=3.57, \mathrm{SD}=0.94) \text {. However, the level of HRM } \\
\text { ractices in terms of management of pay \& bonus schemes }(\mathrm{M}=3.05, \mathrm{SD}=0.94) \text { and performance appraisal \& } \\
\text { nanagement }(\mathrm{M}=2.98, \mathrm{SD}=0.89) \text { is considered moderate. Out of these four functional HRM practices, more focus } \\
\text { s given to personnel selection and placement. On the other hand, the least focus is given to performance appraisal }\end{array}$} \\
\hline
\end{tabular}

\subsection{Comparative Functional HRM Practices}

This section presents the comparative functional HRM practices in commercial banks and insurance companies of Nepal. The following Table (5) shows the differences in means:

Table 5: Descriptive Statistics of Functional HRM practices

\begin{tabular}{lccccc}
\hline \multirow{2}{*}{ HRM practices } & \multicolumn{5}{c}{ Organizations } \\
\cline { 2 - 5 } & \multicolumn{2}{c}{$\begin{array}{c}\text { Commercial Banks } \\
(\boldsymbol{N = 1 1 9 )}\end{array}$} & $\begin{array}{c}\text { Insurance Companies }(\boldsymbol{N} \\
\text { = 70) }\end{array}$ & \multirow{2}{*}{ F } \\
\hline Employee selection and placement & Mean & S.D. & Mean & S.D. & \\
\hline Training and development & 3.71 & 0.82 & 3.47 & 0.91 & $4.41^{* *}$ \\
\hline Performance appraisal and management & 3.61 & 1.08 & 3.49 & 0.89 & 10.12 \\
\hline Management of pay and bonus schemes & 3.03 & 0.78 & 2.89 & 1.53 & 5.72 \\
\hline
\end{tabular}

Note: Significant at $* p<0.05, * * p<0.01$

The results show that there are significant differences in functional HRM practices between commercial banks and insurance companies. As we can see from the results, commercial banks have generally a higher level in HRM practice indicators whereas insurance companies have generally lower levels of HRM practices. Across the four functional HRM practices, however, significant differences are found only in employee selection and placement and management of pay \& bonus schemes. There are no significant differences in the practice of training $\&$ development and performance appraisal \& management in both commercial banks and insurance companies.

\section{Discussion and Conclusion}

This research gave an overview and discussion of functional HRM practices at Nepal's commercial banks and insurance companies. The results show that more emphasis is given to employee selection and placement out of the four functional HRM practices that are followed by pay \& bonus systems management in our context. Nepalese commercial banks and insurance companies offer the least attention to performance appraisal and management. In fact, formal selection and placement procedures, use of tests, job descriptions, and requirements are top of the priority. Likewise, training and development in terms of orientation, needs analysis, programs design, and evaluations, and management of pay \& bonus schemes in terms of performance link, bonus system, profit-based, and team-based schemes are also considered at some level whereas performance appraisal \& management in terms of regularity, formal forms, specific criteria, and specific rules are not considered so much.

The findings also point out that there are significant differences between commercial banks and insurance companies in functional HRM practices in terms of employee selection and placement and in the management of pay $\&$ bonus schemes. Commercial banks are often found to typically have a higher level of HRM practices, while 
insurance companies have a lower level of HRM practices. This means that there is a possibility of the mobility of human resources from insurance companies to commercial banks. In addition, insurance companies are more likely to produce more staff turnover, while commercial banks may be more likely to recruit talent and skilled workers from both insurance companies and the job market. Indeed, efficient human resource management generates and sustains competitive advantage and enhances organizational efficiency. This finding is steady with the conclusions of previous studies (e.g., Beckesr \& Gerhart, 1996; Singh Narang \& Sharma, 2014; Chopra, 2017; and Hamadamin $\&$ Atan, 2019). Therefore, both commercial banks and insurance companies in Nepal must ensure that investment in their human resources and HRM practices definitely attract and retain competent people from the job market.

\section{References}

Alima, A.K., \& Faizuniah, P. (2018). Mediating role of organizational commitment in the relationship between human resource management practices and employee engagement. International Journal of Sociology and Social Policy, 38(7/8), 606-636, doi: 10.1108/IJSSP-08-2017-0097.

Ana, C., Gisela, D., \& Tatiane, P. (2019). Do human resources policies and practices produce resilient public servants? Evidence of the validity of a structural model and measurement models. Revista Brasileira de Gestao de Negocios, 21(1), 70-85, doi: 10.7819/rbgn.v21i1.3965.

Barney, J. (1991). Firm resources and sustained competitive advantage. Journal of Management, 7(1), 99-120.

Becker, B., \& Huselid, M. A. (1998). High performance work systems and firm performance. A synthesis of research and managerial implications. In:Ferris G.F.(ed). Research in Personnel and Human Resources, 16(1), 53-101.

Beckesr, B., \& Gerhart, B. (1996). The impact of human resource management on organizational performance: progress and prospects. Academy of Management Journal, 39(4), 779-801.

Cherif, F. (2020). The role of human resource management practices and employee job satisfaction in predicting organizational commitment in Saudi Arabian banking sector. International Journal of Sociology and Social Policy, 40(7/8), 529-541.

Chopra, R. (2017). Strategic Human Resource Management and its Impact on Organisational Performance. Global Journal of Enterprise Information System, 9(3), 89-93.

Delaney, J. T., Lewin, D., \& Ichniowski, C. (1989). Human resource policies and practices in American firms. Washington: Bureau of Labor-Management Relations and Cooperative Programs, U.S. Department of Labor, BLMR \#137.

Delery, J. E., \& Doty, D. H. (1996). Modes of theorizing in strategic human resource management: tests of universalistic, contingency, and configurational performance predictions, Academy of Management Journal, 39(4), 802-835.

Dyer, L. (1985). Strategic human resource and planning. In K. Rowland and G. Ferris (Ed. Research in Personnel and Human Resource Management, 3, 1-30. Greenwich, CT: JAI Press.

Dyer, L., \& Reeves, T. (1995). Human resource strategies and firm performance: What do we know and where do we need to go? International Journal of Human Resource Management, 6(1) 656-670.

Elrehail, H., Harazneh, I., Abuhjeeleh, M., Alzghoul, A., Alnajdawi, S., \& Ibrahim, H. (2019). Employee satisfaction, human resource management practices and competitive advantage. European Journal of Management and Business Economics, 29(2), 125-149.

Ferris, G. R., Hochwarter, W. A., Buckley, M. R., Harrell-Cook, G., \& Frink, D. D. (1999). Human resource management: some new directions. Journal of Management, 23(3), 385-415.

Foot, M., \& Hook, C. (2005). Introducing human resources management, 4th Ed., Prentice-Hall, Pearson Education.

Guest, D. E. (1997). Human resource management and performance: a review and research agenda. International Journal of Human Resource Management, 8(1): 263-276.

Guest, D. E. (1999). Human resource management-The worker's verdict. Human Resource Management Journal, 9(3), 5-25.

Guest, D. M. (2003). Human resource management and corporate performance in the UK. British Journal of Industrial Relations, 41(2), 291-314.

Hamadamin, H.H., \& Atan, T. (2019). The Impact of Strategic Human Resource Management Practices on Competitive Advantage Sustainability: The Mediation of Human Capital Development and Employee Commitment. Sustainability, 11, 1-19. doi:10.3390/su11205782

Harel, G. A. (1999). The effect of human resource management practices on the perceptions of organizational and market performance of the firm. Human Resource Management, 38, 85-200.

Huselid, M. A. (1995). The impact of human resource management practices on turnover, productivity and corporate financial performance. Academy of Management Journal, 38(3), 635-672.

Jackson, S. E., \& Schuler, R. S. (1995). Understanding human resource management in the context of organizations and their environments, Annual Review of Psychology, 46(1), 237-260 
Jackson, S.E., Schuler, R.S., \& Werner, S. (2009). Managing human resources. Mason, OH: South-Western Carnage Learning, p. 230-233.

Jaradat.S.A., \& Azaam, A.A. (2013). Impact of Human Resources Management practices on Achieving competitive Advantage for Industrial companies (An Empirical study at Al Hassan Industrial Estate-Jordan). Information and Knowledge Management, 3(12), 29-39.

Laursen, K., \& Foss, N. J. (2003). New human resource management practices, complementarities and the impact on innovation performance. Cambridge Journal of Economics, 27(2), 243-263.

Ling, T.C., \& Mohd, A. (2010). Human resource management practices and organizational innovation: An empirical study in Malaysia. The Journal of Applied Business Research, 26(4), 105-115.

Mizanur, R., Mohammad, J., \& Mohammad, A. (2013). The role of human resource management practices on job satisfaction and organizational commitment in banking sector of Bangladesh- A comparative analysis. Journal of Faculty of Business Administration, Part-C, 9 (1/2), 1-13.

Mohammad, R., Rubelad, N., Newaz, R., Yuslizac, D., \& Mui, H. (2018). High commitment human resource management practices and employee service behaviour: trust in management as mediator. IIMB Management Review, 30(4), 316-329.

Pfeffer, J. (1994). Competitive advantage through people. California Management Review, 36(2), 9-28.

Poole, M., \& Jenkins, G. (1997). Responsibilities for human resource management practices in the modern enterprise: Evidence from Britain. Personnel Review, 26(5), 333-356. https://doi.org/10.1108/00483489710176039

Quansah, N. (2013). The impact of HRM practices on organisational performance: the case study of some selected rural banks. Unpublished Thesis, Kwame Nkrumah University of Science and Technology, Ghana.

Qureshi, M., Tahir Hijazi, T., Syed Ramey, I., \& Mohammad (2007). Impact of Human Resource Management practices on Pakistani organizations. Journal of Business Policy Research, 3(2), 128-138.

Schuler, R. S. (1989). Strategic human resource management and industrial relations. Human Relations, 42(2), $157-184$.

Sekaran, U. (2006). Research methods for business: A skill-building approach. New York: John Wiley and Sons, Inc.

Shipton, H., D. Fay, M. West, Patterson, M., \& Birdi, K. (2005). Managing People to Promote Innovation. Creativity and Innovative Management, 14(2), 118-128.

Shrestha, P. (2013). Perceived organizational justice and job performance. Germany: Lap Lambert Academic Publishing.

Shrestha, P. (2016). Organizational justice and employee work outcomes in service sector of Nepal. Unpublished $\mathrm{PhD}$. dissertation submitted to Office of the Dean, Faculty of Management, Tribhuvan University, Kathmandu, Nepal.

Shrestha, P. (2019). Job involvement as an outcome of organizational justice. NCC Journal, 4(1), 149-156. https://doi.org/10.3126/nccj.v4i1.24748

Shrestha, P. (2020). Managerial perceptions on internal marketing and employee commitment in Nepal. Journal of Balkumari College, 9(1), 41-47. DOI: https://doi.org/10.3126/jbkc.v9i1.30066

Shrestha, P., \& Parajuli, D. (2020). Impact of merger and acquisition practice on job stress: Evidence from Nepal. European Journal of Business and Management, 12(24), 1-8. DOI: 10.7176/EJBM/12-24-01

Singh Narang, M.G.G. \& Sharma, A. (2014). Achieving competitive advantage through hr practices. International Research Journal of Humanities, Engineering \& Pharmaceutical Sciences, 4(7), 19-26.

Uma, S., Aurolipy, \& Madhusmita, D. (2017). Impact of HRM practices on job satisfaction and performance: an empirical study in health care sector. International Journal of Economic Research, 14(2), 95-105.

Wang, Z., \& Zang, Z. (2005). Strategic human resources, innovation and entrepreneurship fit: A cross-regional comparative model. International Journal of Manpower, 26(6), 544-559.

Wright, P. M., \& McMahan, G. C. (1992). Theoretical perspectives for strategic human resource management. Journal of Management, 18(2), 295-320. 